\title{
QUANTITATIVE EVALUATION OF FINDINGS IN THE EPITHELIUM OF TERMINAL BRONCHIOLES IN HEALTHY RABBITS (Oryctolagus cuniculus var. edulis)
}

\author{
J.UHLÍK \\ Institute of Histology and Embryology, $2^{\text {nd }}$ Medical Faculty, Charles University, Prague
}

Received July 23, 1996

Accepted October 21, 1996

\begin{abstract}
Uhlík, J:: Quantitative Evaluation of Findings in the Epithelium of Terminal Bronchioles in Healthy Rabbits (Oryctolagus cuniculus var. edulis). Acta vet. Brno 1996, 65:181-184.

The ultrastructure of the epithelium of terminal bronchioles in healthy control rabbits was evaluated quantitatively. The simple epithelium of terminal bronchioles was composed of ciliated cells and secretory Clara cells. The ciliated cells were low columnar or cuboidal, their apical surfaces carried only several tens of kinocilia that were not arranged to the continuous ciliary border. The high, columnar Clara cells overtopped and often even overlapped the ciliated ones by their voluminous apical portions. The ultrastructure of both cell types was found conformable to this described in the literature. The Clara cells slightly prevailed in number. They represented $52.7 \pm 3.6 \%$ of epithelial cells. In $73.5 \pm 9.4 \%$ of them secretory granules were discovered.
\end{abstract}

Terminal bronchioles, ciliated cells, Clara cells, ultrastructure

In our previous experiments the effect of different drugs, therapeutic or diagnostic procedures on the ultrastructure of the large extrapulmonary airways' epithelium was studied. A new method of the quantitative evaluation of findings in this epithelium and the classification of the degree of injury to this epithelium was proposed (K on rád ová 1991, 1995).

We decided to extend our studies also to the terminal branches of the bronchial tree, where the pseudostratified columnar ciliated epithelium was gradually substituted by a simple epithelium and the goblet cells were replaced by the Clara ones.

To be able to evaluate the changes caused by different experimental procedures in the epithelium of terminal bronchioles we tried to perform a method of the quantitative evaluation of the ultrastructure of this epithelium in healthy control rabbits.

\section{Materials and Methods}

Three clinically healthy rabbits (males, body mass $1.740 \mathrm{~g}-3.800 \mathrm{~g}$ ) were used. Under general anaesthesia the lungs were removed and one of them was immediately perfused by $5 \%$ glutaraldehyde in $0.1 \mathrm{M}$ cacodylate buffer $(\mathrm{pH} 7.2)$ through a plastic cannula introduced to the main bronchus. One of the perfused lungs was then transversely sectioned and tiny pieces of the tissue were collected and fixed for 90 min with $5 \%$ glutaraldehyde in $0.1 \mathrm{M}$ cacodylate buffer and then for $60 \mathrm{~min}$ with $2 \% \mathrm{OsO}_{4}$ in $0.1 \mathrm{M}$ cacodylate buffer $(\mathrm{pH} 7.4)$. The material was dehydrated in graded series of alcohol and embedded in a Durcupan-Epon mixture. Terminal bronchioles were localized in semithin sections stained with toluidine blue ( $1 \%$ toluidine blue in $9.46 \%$ aqueous $\mathrm{Na}_{2} \mathrm{HPO}_{4}$ solution). Ultrathin sections were prepared on Ultrotome Nova, contrasted with uranyl acetate and lead citrate and examined in JEM 100 C electron microscope.

In the course of quantitative evaluation the total number of ciliated and Clara cells and functional state of Clara cells were recorded in the electron microscope. A total of 284 ciliated cells was counted and of the 317 Clara cells only in 233 secretory granules were encountered (Table 1).

\section{Results}

Terminal bronchioles of healthy rabbits were lined by simple epithelium where low columnar or cuboidal ciliated cells and high columnar Clara cells almost regularly 
Table 1

Quantitative evaluation of the epithelium of terminal bronchioles in control rabbits (absolute values)

\begin{tabular}{|l|c|c|c|c|}
\hline Rabbit & No.1 & No.2 & No. 3 & total \\
\hline Ciliated cells & 127 & 77 & 80 & 284 \\
\hline Clara cells & 123 & 96 & 98 & 317 \\
\hline \hline CC with granules & 79 & 73 & 81 & 233 \\
\hline CC without granules & 44 & 23 & 17 & 84 \\
\hline
\end{tabular}

$\mathrm{CC}=$ Clara cells

alternated. Clara cells highly protruded into the lumen of bronchioles and by their conical or dilated apical portions overlapped the surfaces of the ciliated ones (Plate III., Fig. 1). By means of dilated apical portions the Clara cells sometimes almost isolated the ciliated ones from the airways' lumen. We did not find any other cells in the terminal bronchioles' epithelium.

Apical junctional complexes between epithelial cells were well developed (Fig. 2). Many isolated desmosomes were also encountered on the lateral cell surfaces.

Epithelial cells rested on a well developed basal lamina. In the layer of a loose connective tissue of the lamina propria mucosae extensive masses of the elastic fibers were often found (Fig. 3). A relatively thick layer of smooth muscle cells was observed under the lamina propria mucosae.

The ciliated cells contained spherical, basally situated nuclei with a high content of euchromatin. Their cytoplasm was rich in mitochondria with electron dense matrix and numerous cristae. The mitochondria were concentrated especially in the apical portions of the cytoplasm. They were ovoid or elongated in shape with their long axis parallel to the long axis of the cell (Figs 1,2). Many free ribosomes and polyribosomes were found in the cytoplasm. Tiny lysosomes or larger vacuoles containing heterogenous material were often observed. Multivesicular bodies regularly occurred mostly in apical portions of the cytoplasm (Fig. 2). Isolated cisternae of the rough endoplasmic reticulum, not very well developed Golgi complex and several transport vesicles were also noticed. Exceptionally extensive intracytoplasmic ciliated vacuoles were encountered (Fig. 4). The elements of the cytoskeleton were very well developed in the ciliated cells. A dense network of microfilaments and numerous long isolated microtubules were found mostly in apical portions of these cells. The ciliary apparatus of typical appearance was developed on the apical surface (Figs 1,2). The ciliated cells of the terminal bronchioles were equipped with lower number of cilia compared with those in larger airways. Only several tens of cilia were usually encountered on their surfaces. The microvilli prevailed on the apical surfaces (Figs $1,2)$. The voluminous protrusions of the neighbouring Clara cells reduced the area of the ciliary border and contributed to the rather oblique orientation of the cilia. Instead of regular ciliary border only isolated tufts of cilia were observed above individual ciliated cells.

Oval, light nuclei of Clara cells were situated in the central area or near the base of these cells. The apical portion of their cytoplasm was rich in tubules of the smooth endoplasmic reticulum filled by the moderately electron dense material (Plate IV., Fig. 5, 6). Numerous parallel cisternae of the rough endoplasmic reticulum were situated in the basal portions of the cytoplasm (Fig. 7). The cisternae were usually narrow without any signs of product accumulation. Golgi complex was not very extensive. Cytoplasm of the Clara cells 
contained numerous mitochondria. Together with the small mitochondria of the usual appearance also large, spherical or oval ones with the less electron dense, finely granular matrix and a few cristae, situated usually in the apical portions of the Clara cells' cytoplasm, were observed (Fig. 6,8). In the majority of the Clara cells oval or slightly irregular secretory granules mostly filled with highly electron dense, homogenous content were encountered (Fig.8). In some of them small, spherical, eccentrically located, light area was found. Electron lucent granules were exceptionally also observed. The granules were mostly concentrated in the apical portions of the cells just under the plasma membrane. The apical surfaces of the Clara cells carried only a few short, wide microvilli (Fig.1, 5).

In the epithelium of the terminal bronchioles of healthy rabbits the secretory Clara cells slightly prevailed. They represented $52.7 \pm 3.6 \%$ of epithelial cells. In the majority of them $(73.5 \pm 9.4 \%)$ secretory granules were discovered, only $26.5 \pm 9.4 \%$ did not reveal the secretory activity.

\section{Discussion}

The ultrastructure of the epithelial cells of rabbits' terminal bronchioles was described in numerous papers (Breeze and Wheld on 1977; Gail and Lenfant 1983; Jeffery 1983; Kil bu r n 1974; Plop p e r et al. 1980a). Our findings coincide completely with these descriptions. Only Smith with co-workers found dilated tubules of smooth endoplasmic reticulum in healthy control rabbits ( $\mathrm{S} \mathrm{mith}$ et al. 1979). In agreement with other authors (Harke ma et al. 1993; Plopper et al. 1994) we consider this finding to be one of the signs of the Clara cells' pathological alteration.

The quantitative evaluation of the ultrastructure of the epithelium of the terminal bronchioles was performed by several authors. Their results differed according to the studied species. Interspecies differences in the relative number of individual cells in this epithelium were described in the comparative studies of Plopper and his fellow-workers (Plopper 1983; Plop per et al. 1980ab). According to these authors the Clara cells represented from about $50 \%$ of epithelial cells in hamsters and cattle to nearly $100 \%$ in cats and dogs.

Hyde and his fellow-workers and in some studies also Plopper noticed the conspicuous prevalence of the secretory Clara cells over the ciliated ones in the epithelium of rabbits' terminal bronchioles (Hyde et al.1983; Plopper 1983; Plopper et al. 1980a). According to these authors the percentage of the Clara cells varied between 66.2 and $67.4 \%$ of all epithelial cells.

Only in the last paper Plopper described the nearly equal occurrence of ciliated and Clara cells in the epithelium of rabbits' terminal bronchioles (48.7\% of ciliated cells, $47.3 \%$ of Clara cells and $3.9 \%$ of other or uncategorized cells) (Plop per et al. 1983). These results are very similar to our findings in the bronchiolar epithelium of the healthy control rabbits.

\section{Kvantitativní hodnocení nálezů v epitelu terminálních bronchiolů zdravých králíků (Oryctolagus cuniculus var. edulis)}

Hodnotili jsme kvantitativně ultrastrukturu epitelu terminálních bronchiolů zdravých kontrolních králíků. Jednovrstevný epitel terminálních bronchiolů byl tvořen řasinkovými buňkami a sekrečními Clara buňkami. Řasinkové buňky byly nízce cylindrické až kubické, jejich apikální povrchy nesly jen několik desítek kinocilií, jež nebyly uspořádány do souvislého řasinkového lemu. Vysoké, cylindrické Clara buňky převyšovaly a často svými širokými apikálními částmi dokonce préekrývaly buňky řasinkové. Ultrastruktura obou buněčných typů se shodovala s údaji z literatury. Clara buňky svým počtem lehce převažovaly. Představovaly $52,7 \pm 3,6 \%$ epitelových buněk. V 73,5 $\pm 9,4 \%$ z nich jsme nalezli sekreční granula. 


\section{Acknowledgements}

This work was supported by Charles University Internal Grant $\mathrm{N}^{\mathrm{O}} 234$.

\section{References}

BREEZE, R. G., WHELDON, E. B. 1977: The cells of the pulmonary airways. Am. Rev. Respir. Dis. 116:705-777 GAIL, D. B., LENFANT, C. J. M. 1983: Cells of the Lung: biology and clinical implications. Am. Rev. Respir. Dis. 127:366-387

HARKEMA, J. R., PLOPPER, C. G., HYDE, D. M., ST.GEORGE, J. A., WILSON, D. W., DUNGWORTH, D. L. 1993: Response of macaque bronchiolar epithelium to ambient concentrations of ozone. Am. J. Pathol. 143:857-866

HYDE, D. M., PLOPPER, C. G., KASS, P. H., ALLEY, J. L. 1983: Estimation of cell numbers and volumes of bronchiolar epithelium during rabbit lung maturation. Am. J. Anat. 167: 359-370

JEFFERY, P. K. 1983:Morphologic features of airway surface epithelial cells and glands. Am. Rev. Respir. Dis. 128: S14-S20

KILBURN, K. H. 1974:Functional morphology of the distal lung. International Review of Cytology 37:153-269

KONRÁDOVÁ, V. 1991:Quantitative evaluation of the degree of damage to tracheal epithelium. Funct. Dev. Morphol. 1:47-50

KONRÁDOVÁ, V. 1995:Epitel dýchacích cest a jeho reakce na rủzné škodliviny. Čas. lék. Čes. 134:440-444

PLOPPER, C. G. 1983:Comparative morphologic features of bronchiolar epithelial cells. The Clara cell. Am. Rev. Respir. Dis. 128:S37-S41

PLOPPER, C. G., MARIASSY, A. T., HILL, L. H. 1980a: Ultrastructure of the nonciliated bronchiolar epithelial (Clara) cell of mammalian lung: I. A comparison of rabbit, guinea pig, rat, hamster, and mouse. Exp. Lung Res. 1: $139-154$

PLOPPER, C. G., MARIASSY, A. T., HILL, L. H. 1980b: Ultrastructure of the nonciliated bronchiolar epithelial (Clara) cell of mammalian lung: II. A comparison of horse, steer, sheep, dog, and cat. Exp. Lung Res. 1:155-169

PLOPPER, C. G., HASELBO, J. E., BERGER, W. J., SONSTEGARD, K. S., NETTESHEIM, P. 1983: Distribution of nonciliated bronchiolar epithelial (Clara) cells in intra- and extrapulmonary airways of the rabbit. Exp. Lung. Res. 4: 79-98

PLOPPER, C. G., WEIR, A. J., NISHIO, S. J., CHANG, A., VOIT, M., PHILPOT, R. M., BUCKPITT, A. R. 1994: Elevated susceptibility to 4 -ipomeanol cytotoxicity in immature Clara cells of neonatal rabbits. J. Pharmacol. Exp. Ther. 269:867-880

SMITH, M. N., GREENBERG, S. D., SPJUT, H. J. 1979:The Clara cell:A comparative ultrastructural study in mammals. Am. J. Anat. 155:15-30

Address for correspondence:

MUDr. J. Uhlík

Institute of Histology and Embryology

$2^{\text {nd }}$ Medical Faculty, Charles University

$\mathrm{V}$ úvalu 84

CZ-150 18, Praha 5

Czech Republic 
Plate III.

Uhlík J.: Quantitative... pp. 181-184


$005.850 \mathrm{ct}$ 00,6 .4.

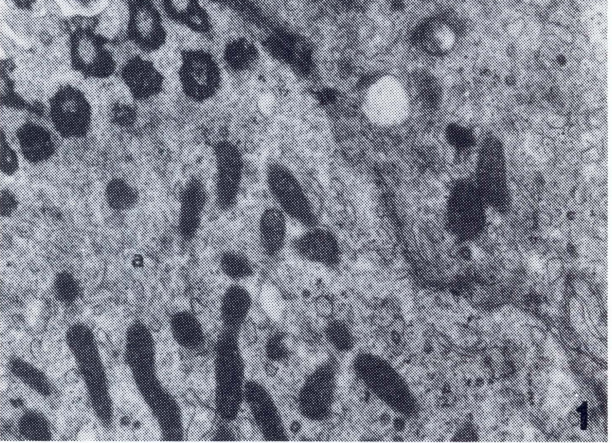

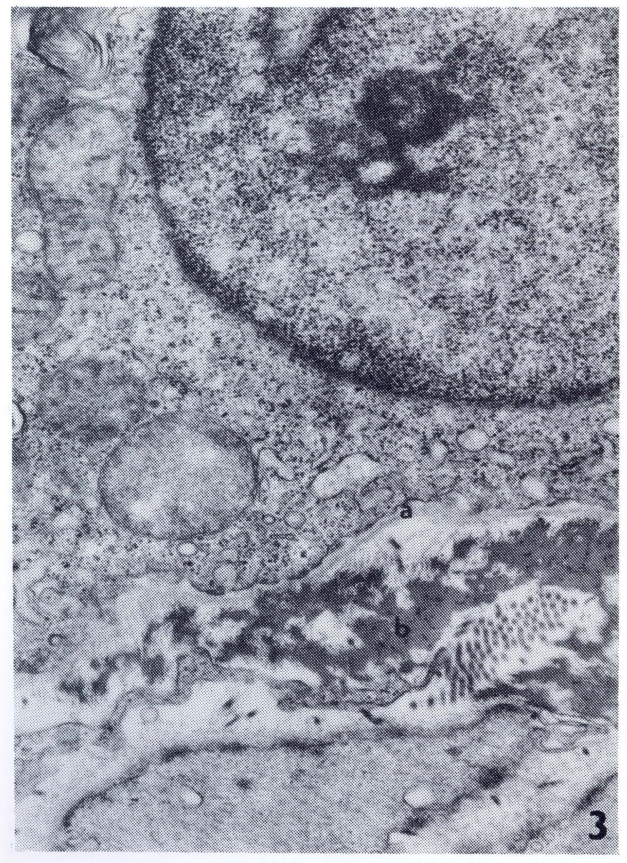

(2)

a.

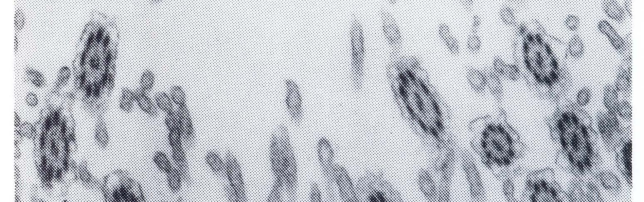

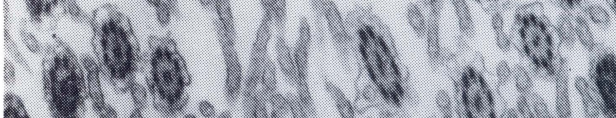
3.

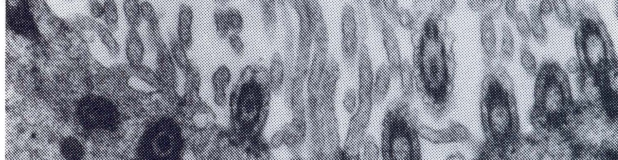

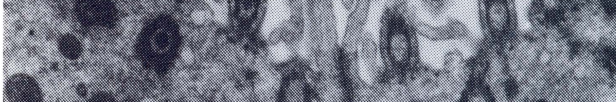

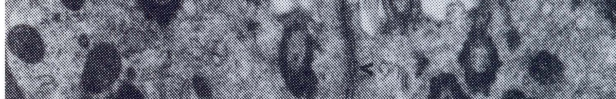

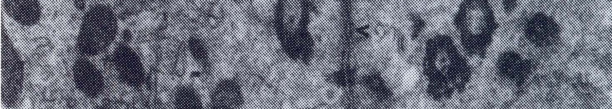

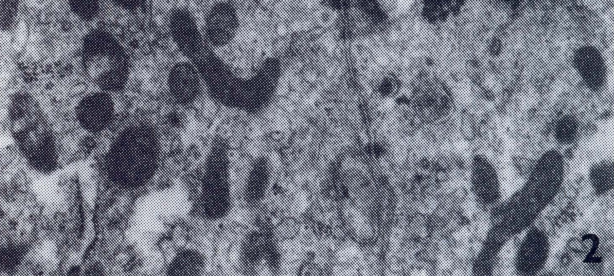

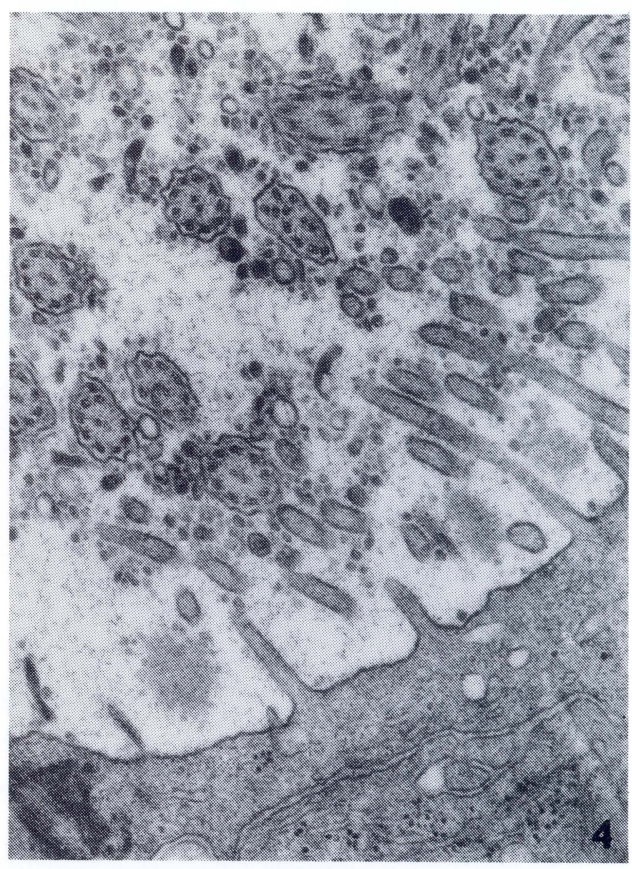




\section{Description of figures}

Plate III.

Fig.1. Apical portions of the ciliated (a) and Clara (b) cells. $25000 \mathrm{x}$

Fig.2. Apical junctional complex between two ciliated cells (arrowhead). $25000 x$

Fig.3. Basal portion of the epithelium separated by the basal lamina (a) from the lamina propria mucosae rich in elastic fibers (b). $25000 x$

Fig.4. Extensive intracytoplasmic ciliated vacuole in the cytoplasm of the ciliated cell. $50000 \mathrm{x}$ 
Plate IV.
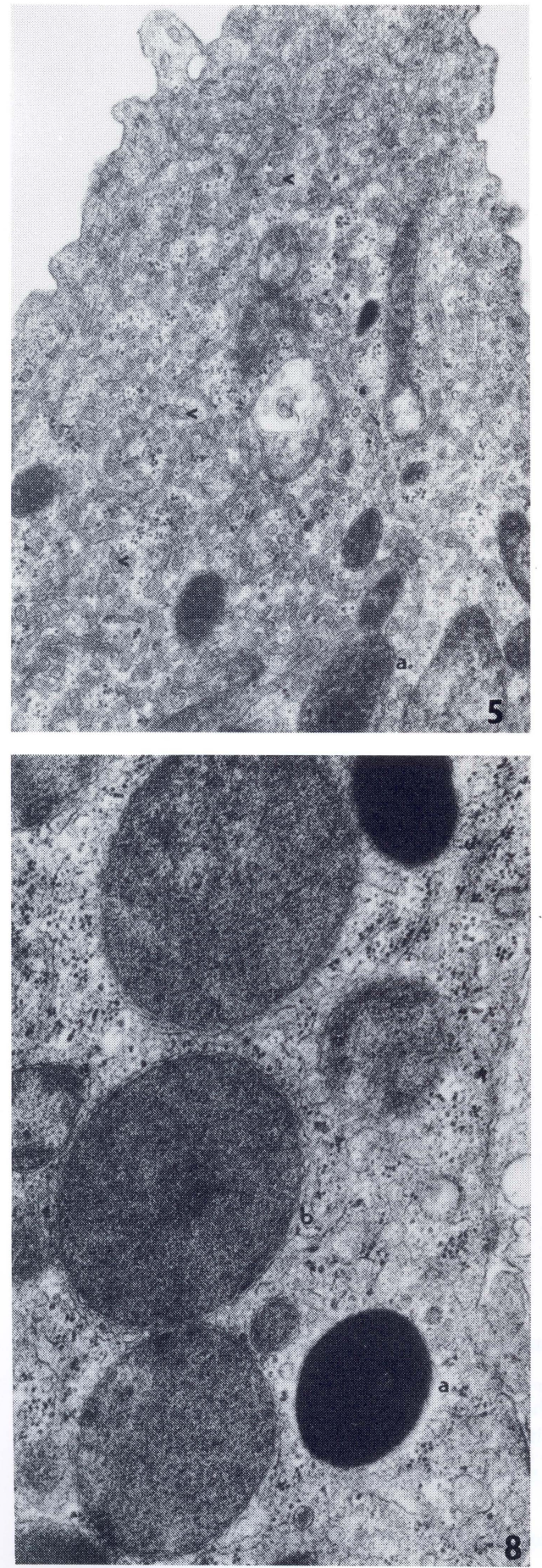
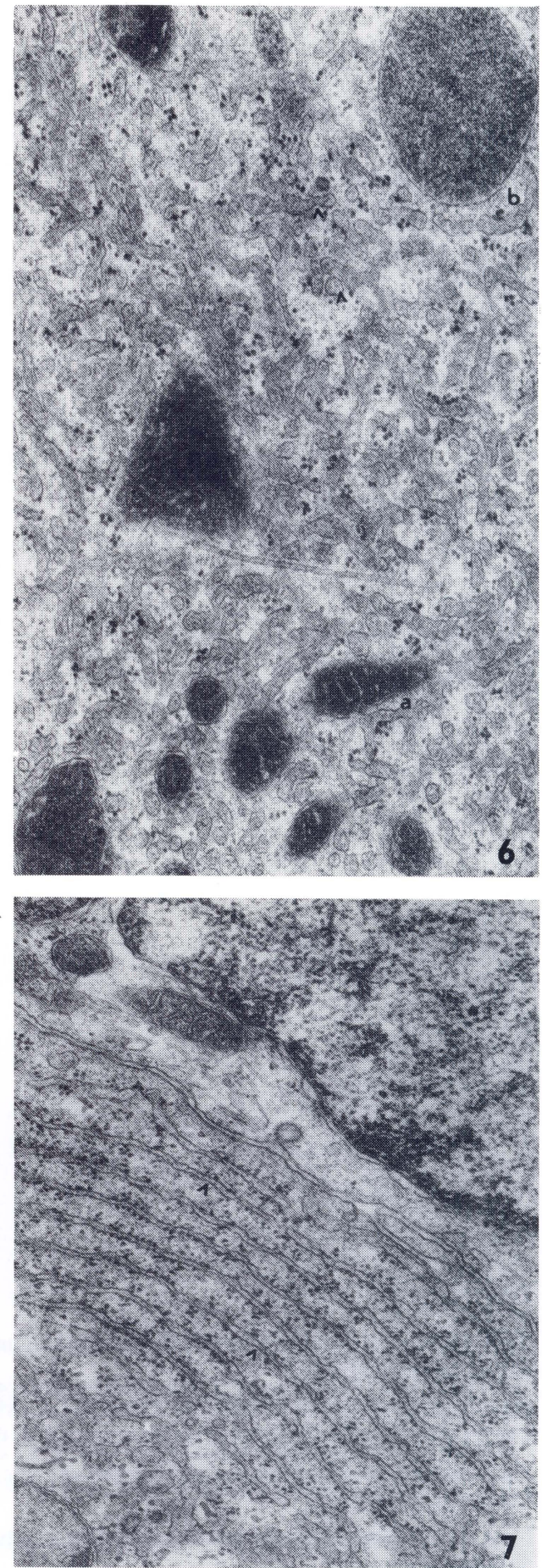
Plate IV.

Fig.5. Numerous tubules of smooth endoplasmic reticulum (arrowheads) and mitochondria (a) in the apical portion of the Clara cell. $37500 x$

Fig.6. Tubules of smooth endoplasmic reticulum (arrowheads), tiny mitochondria with numerous cristae (a) and a large, spherical mitochondrion (b) in the cytoplasm of the Clara cell. $62500 \mathrm{x}$

Fig.7. Parallelly arranged cisternae of rough endoplasmic reticulum (arrowheads) situated beneath a nucleus of the Clara cell. $50000 \mathrm{x}$ Fig.8. Electron dense secretory granules (a) and large, spherical mitochondria (b) in the cytoplasm of the Clara cell.
$50000 \mathrm{x}$ 